COF正SFOITDEINOF.

\title{
THE CARRARA MARBLE DISTRICT (APUAN ALPS).
}

Siz,-In reply to Professor Bonney's remarks on p. 47 of the Geological Magazine of January, suffice it to point out (1) that the determination of the age of the crystalline schists and of the marble beds is essentially a question of palæontological and stratigraphical evidence, which, as I have shown, is absolutely conclusive, and is, moreover, universally accepted; (2) that it was neither the object nor within the available space of my paper to enter into the details of microscopical examination, the less so as this part of the subject has been exhaustively dealt with in the recent memoirs of Professor d'Achiardi, of Pisa, and of Mattirolo and Franchi of the Italian Geological Survey; (3) that the district of the Apuan Alps is pre-eminently one which, owing to its extent and complexity, requires long and patient study of the entire area, and cannot be mastered by two admittedly incomplete visits, of only a few hours each, barely beyond one point of its periphery.

EDINBURGH.

C. Du Riche Preller.

January 12, 1916.

THE CRYSTALLINE ROCKS OF THE PIEMONTESE ALPS.

SrR, - In a footnote ( $p$. 16) of my paper on the Permian formation of the Maritime and Western Alps in the Geological Magazine of January, I mentioned that I propose to deal in a subsequent paper more fully with the crystalline schists and the pietre verdi areas, also in relation to the anti-Archæan and pro-Mesozoic views of Franchi as opposed to those of Zaccagna. In the meantime I should perhaps mention that in the most recent Italian geological maps just come to my notice the extensive crystalline calc-schist formation, which up to 1969 figured as pre-Pulæozoic, has been rejuvenated to Mesozoic.

EDINBURGH.

C. Do Ricae Preller.

January $12,1916$.

\section{OBITUARY. \\ ARTHUR VAUGHAN, \\ B.A. (Cant.), M.A. (Oxon.), D.Sc. (Lond.). \\ BorN MarCH, 1868. \\ DIED DECEMBER 3, 1915.}

(WITH a PORTRAIT, PLA'TE V.)

THe death at the early age of 47 of Dr. Arthur Vaughan, which took place at Oxford on December 3, removes one of the most brilliant of British stratigraphical geologists.

Dr. Vaughan was the son of the late William Vaughan, F.I.A., Actuary to the Board of Trade, and was born in London in 1868. After a highly successful career at University College School, he entered University College, London, in 1885, and there acquired his first interest in geology from the influence of Professor Bonney. In 1887 he entered Trinity College, Cambridge, with an open scholarship, 